\title{
The Non-profit Sector in Russia in the Global Economy View
}

\author{
N.I. Ivanova ${ }^{1, *}$ \\ ${ }^{*}$ Corresponding author: cleotasha@ rambler.ru \\ ${ }^{1}$ Samara State University of Economics, Samara, Russia
}

\begin{abstract}
The non-profit sector is growing and expanding worldwide. In Russia it is still underdeveloped due to the reasons revealed in the paper. Non-profit organizations (NPOs) have particular features in each country (starting with their legal definition ending with their size and global ambitions). So they do in Russia. These specific traits have been summarized, reasoned and explained using the qualitative approach and inductive interpretivism. This will help to fill the gap in literature on NPOs in Russia and surely prove that the non-profit sector does exist in Russia and keeps developing. The revealed features may as well help to adopt in Russia the foreign experience of developing the non-profit sector. The results obtained can further scientific research on NPOs in Russia and help the government to provide the sector with specific and adequate support.
\end{abstract}

Keywords: non-profit sector, voluntary sector, non-profit organization (NPO), non-governmental organization (NGO), charitable organizations, tax-exempt organizations.

\section{Introduction}

The non-profit sector is expanding rapidly [1-5]. At least ten years ago the sector was as big as the eighth economy in the world exceeding a trillion US dollars and embracing up to 19 million paid employees [6-8]. In the USA alone there were 12,000 registered nonprofits in 1940 and 1.41 million in 2013 [9], and there are over 1.5 million today.

About 10 million NPOs operate round the globe today [10]. Nonprofits are mostly small- and medium-sized [9]. Though the annual budgets of some larger NPOs overtop these of certain countries [11]. Let's take an example: WorldVision states the revenue of approximately 3 billion US dollars [12]; Save the Children - over 678 million in the US alone in 2015.

Most medium- and large-size NPOs are present internationally, thus influencing the global economy [13-15]. NPOs in Russia - their objectives and fields of activities - are similar to those operating abroad. The specific Russian NPOs' traits include scarce financing and resultant underdevelopment. However Russian government pays more attention to NPOs today as they help the government to maintain the environment and social sphere.

\section{Problem Statement}

Experts identify the rapid worldwide growth and expansion of the non-profit sector as the "association revolution" [4] expecting it to be as significant as the rise of nation-states a century earlier. But the various definitions NPOs have in literature restrain the analysis and empirical comparison of this growth. The US today is perhaps the only country in the world that possesses the most developed system of identifying, recognizing and registering NPOs. Many countries however lack such a formal system. This makes it difficult to reveal the essence, traits and quantitative features of NPOs and the non-profit sector in a particular country and constrains reliable cross country comparisons. So, NPOs are definitely not among the most researched areas. Russian NPOs and foreign NPOs acting in Russia remain almost absolutely scientifically unstudied.

\section{Research Questions}

The major research questions is "What is an NPO in Russia?". "What traits make Russian NPOs specific in comparison with those operating abroad?" is the sub-question.

\section{Purpose of the Study}

The purpose of the study is to reveal the major traits of Russian NPOs. These traits may help to a) adopt in Russia the foreign experience of developing the non-profit sector; b) create adequate, effective and Russia-specific mechanisms of governmental support for NPOs. 


\section{Research Methods}

The methods chosen for the research are based primarily on the qualitative approach with a particular stress on the analysis of texts, documents and related data. Explanations given in the paper are inductive - each explanation is induced from the relevant data. The research philosophy is interpretivism [16]. The research design is descriptive with the main aim to describe and examine the factors having a particular place and time. The research method is causal comparative research that identifies the cause-effect relationships [17].

\section{Findings}

Available literature provides rather a vague definition of the non-profit sector.

In the US - the country that is considered to have the strongest non-profit sector - the sector embraces tax-exempt organizations being neither market nor public (governmental).

Terms implied in different senses are used to identify the sector itself and the organizations acting within it. Let's name a few: voluntary sector, charitable organizations, non-profit organizations, non-governmental organizations, économie sociale. The latter is used in France and Belgium [18].

McCarthy K.D., Hodgkinson V.A., Sumariwalla R.D., and Associates distinguish similar cross country traits that unite NPOs worldwide: "They are organizations formed to serve the public good, and income (or profits) from these organizations are not distributed to members or owners" [19]. Salamon L.M. addresses the non-profit sector as "a massive array of self-governing private organizations, not dedicated to distributing profits to shareholders or directors, pursuing public purposes outside the formal apparatus of the state" [4].

The following definition types are used by Salamon L.M. and Anheier H.: NPO;

1. Legal - means the requirements that each country sets for an organization to be considered and registered as an

2. Economic/financial - focuses on the funding sources received by an NPO;

3. Functional - stresses the objectives of an NPO (social, environmental, etc.);

4. Structural/operational - emphasizes the basic structure of an NPO. The economic actor of this type is to be a) organized; b) private; c) non-profit-distributing; d) self-governing; and e) voluntary [18].

Another term linked to the non-profit sector that has drawn our attention is a non-governmental organization (NGO). The United Nations describes an NGO as a not-for-profit, voluntary citizens' group, which is organized on a local, national or international level to address issues in support of the public good. This sounds capacious, but the NGOs that are recognized neither nationally nor internationally, and those that do not fit the UN goals and principles are excluded from the definition. So, the latter does not comprise the non-profits that set local objectives (e.g., the American Heart Association and the Boys and Girls Clubs of America - the known US NGOs - are not on the UN list).

An NGO is definitely a narrower term than an NPO. International Non-Governmental Organizations (INGOs) being a special type of NPOs are numerous today. In the US alone there were 1,505 INGOs in 1990 and 6,134 in 2000 . It's an astonishing growth exceeding four hundred percent [20].

Russian legislation defines an NPO as an organization that does not set profit as the main goal of its operation and does not distribute profit among the participants [21].

Below we shall induce and summarize the traits of Russian NPOs.

Russian NPOs being underfinanced have to be highly flexible. NPOs abroad receive permanent and sufficient funding. European government institutions invest millions of euro in the non-profit sector [7, 9] supporting its smooth non-innovative operation. Russian NPO legislation keeps developing and changing. This surely undermines the sustainability of funding and makes NPOs in Russia alert, flexible and highly ready for innovations.

Another trait making Russian NPOs specific is small staff. NPOs in Russia most commonly act under the direction of a single manager, who is simultaneously a fundraiser, strategist and an HR. This is caused, firstly, by the society's indifference to the non-profit sector and, secondly, by the lack of attention in the media. It's like a vicious circle - the society's indifference makes NPOs underdeveloped and scarcely covered in the media, the society is consequently uninformed on NPOs' activities, so the indifference remains.

This trait is linked to the above. We would name it "lack of adequately trained staff". Funding is provided for special education in Europe. The educational programs for non-profit sector professionals are focused on a wide range of topics - environment, science, health and politics.

The key objectives of Russian NPOs are similar to these of NPOs worldwide:

$\checkmark$ promoting social stability and positive changes in society;

$\checkmark$ developing innovative technologies that can help to satisfy social needs;

$\checkmark$ implementing professional, public and private interests of citizens;

$\checkmark$ protecting human rights;

$\checkmark$ maintaining environmental sustainability and environmental protection, etc.

The National Union of NPOs was established in Russia in 2015 to support the non-profit sector. The Congress of Russian NPOs is an annual platform for NPOs, government and social entrepreneurs to discuss the ways to develop:

$\checkmark$ the national non-profit sector, 
$\checkmark$ sustainability of NPOs,

$\checkmark$ social services,

$\checkmark$ social entrepreneurship,

$\checkmark$ the funding system of the civil society institutions.

The members of the National Union of NPOs are assisted when entering the social services market, supported in the media, legally protected and given an access to the mutual aid bank.

According to the Ministry of Justice, there are over 220 thousand NPOs in Russia with Moscow and Moscow region confidently leading. About a hundred of existing NPOs are on the list of foreign agents. More precisely: 73 NPOs performing the functions of a foreign agent are available through the information portal of the Russian Ministry of Justice - the data valid for December, 2018.

Russian legislation provides several types of funding for NPOs:

$\checkmark$ federal grants (given by the Ministry of Economic Development and the President),

$\checkmark$ regional grants (in the form of subsidies from the regional ministries of economic development, governors' grants),

$\checkmark$ donor funds (funds from larger NPOs and foundations),

$\checkmark$ private donations (patronage).

4.23 billion rubles from the federal budget were invested in 2015 to support the non-profit organizations providing social services and protecting human rights and freedoms. 1.4 thousand of non-profit projects from 78 constituent entities of the Russian Federation received support. The total grant support of NPOs amounted to almost 6 billion rubles in 2015.

There is a special list of 9 NPOs approved by the President that are more heavily funded. The Russian Union of Youth, the Russian Union of Rectors, the Union of Pensioners of Russia, the Union of Women of Russia are on the list.

Private donations are the main source of funding for Russian NPOs. Corporate endowments rank second. Subsidies and grants follow. These are from:

$\checkmark$ local authorities (local municipal budgets),

$\checkmark$ regional authorities (constituent entities' budgets),

$\checkmark \quad$ federal authorities (presidential grants, subsidies from the Ministry of Economic Development).

NPOs are also funded by larger national NPOs and foreign organizations - both for- and non-profit. If an NPO in Russia receives funding from a foreign organization, then it is included in the foreign agent registry kept by the Ministry of Justice.

The problem of scarce NPOs funding is linked to their presence in the registry. The legislation on NPOs that are foreign agents provides a list of reasons to refuse registering such organizations. Lets name a few of the reasons:

$\checkmark$ constituent documents contradict the Constitution of the Russian Federation and the legislation of the Russian Federation;

$\checkmark \quad$ an NPO with the same title already exists;

$\checkmark$ the title of an NPO insults the morality, national and religious feelings of citizens;

$\checkmark$ the set of documents required for state registration is either incomplete or submitted to an inappropriate institution;

$\checkmark$ a person founding an NPO cannot be a founder according to the law;

$\checkmark$ the documents submitted for state registration contain false information.

If an NPO is included in the foreign agent registry, it has to face a number of obstacles. Firstly, foreign agents are obliged to provide more reporting. This leads to extra burden on staff and consequently to additional payments. This requires more funding. If reporting is not submitted on time, then the NPO gets closed. Secondly, the problem of society's mistrust raises. The media often discuss a certain threat to the national security of a country coming from foreign NPOs. This surely forms a negative social attitude.

About $14 \%$ of NPOs in Russia are socially oriented. The share of NPOs in GDP amounts to $0.9 \%$ (estimated in 2013 by the journal "Non-profit Organizations in Russia"). This is much less than in any developed country. Still the progress is evident: according to the statistical data on NPOs provided by the Ministry of Justice, NPOs' total incomes demonstrated the eight times growth - from 70 billion rubles in 2000 to 600 billion rubles in 2015 .

The nonprofits in Russia employed $0.8 \%$ of the labor-force in 2003 . The rate increased slightly over the ten-year period and reached $1.1 \%$ in 2013. Let's give a cross-national comparison: $9.2 \%$ in the USA, $9.0 \%$ in France, $6.8 \%$ in Germany in 2002 (estimated by The Boston Consulting Group).

Funding has been recently cut. This has definitely had a negative impact. According to the Ministry of Economic Development data, foreign funding for NPOs decreased by about 19 billion rubles (about 520 million US dollars) in 2013. This has made NPOs look for extra sources of funding. Thus they have widened the range of services they provide: special attention is now paid to social entrepreneurship, brand-new services for the elderly appear. The increased diversity of services is a positive trend of the sector. It makes authorities regard NPOs as peer and full partners in the social services sector and leads to government support.

One of the largest Russian NPOs is the Foundation for Regional Social Programs "Our Future". It helps to support social entrepreneurship. Social entrepreneurship has started developing in Russia recently. It refers to a special type of activity that implies making profit and reinvesting it in solving or mitigating the most urgent problems in society. Incomes are not distributed among the shareholders, but are invested in such areas as reducing unemployment, protecting the environment and the rights of citizens. "Our Future" is also engaged in charity activities, providing 
assistance to the needy, the disabled, as well as supporting children's camps and sports centers. The main partners are the Center for Social Initiatives, Google Inc., the Global Network of Social Investors and others.

Russian NPOs are also active in the field of business support. This is mainly the objective of the Chambers of Commerce which cooperate worldwide. A Chamber of Commerce is an institution that furthers interaction between business and government and helps to advocate the interests of the business community.

The Russian Chamber of Commerce has been a member of the International Chamber of Commerce (ICC) since 1993. The ICC unites the Chambers of Commerce and business organizations of more than 100 countries. This membership allows the Russian Chamber of Commerce, and hence the regional Chambers of Commerce, to

$\checkmark$ participate in international commissions (on taxes, marketing, banking, international investment, trade, management, environment, intellectual property etc.);

$\checkmark$ receive the publications issued by the ICC;

$\checkmark$ take part in congresses, conferences and other ICC events.

The Russian Chamber of Commerce pays more attention to small and medium-sized businesses, rather than to large and mature companies, since they need much more support.

The Russian Chamber of Commerce has the specific features that make it different from other NPOs in Russia:

$\checkmark$ it is the most territorially widespread NPO in Russia as almost every region has its own Chamber of Commerce;

$\checkmark$ it cooperates actively with the legislative and executive authorities to create a business-friendly environment;

$\checkmark$ it helps government and business to interact performing as a reliable intermediary;

$\checkmark$ it provides assistance for entrepreneurs.

The various functions of the Russian Chamber of Commerce include:

$\checkmark$ providing the services required by the business community (primarily consulting and arbitration);

$\checkmark$ accelerating business development in Russia and promoting foreign trade;

$\checkmark$ holding B2B meetings (the Chamber of Commerce acts as a platform for meetings of Russian and foreign businesses giving an opportunity to exchange information and receive contacts for further cooperation).

The Russian Chamber of Commerce faces "specifically Russian" problems. The key one is delayed payments of membership dues. The Chamber of Commerce in the region of Samara states the arrears of membership dues that amount to about 70\%. The business community in Russia still underestimates the role of the Chamber of Commerce in accelerating business and promoting foreign trade thus hampering the Chamber's development.

\section{Conclusion}

NPOs in Russia act mostly in the social sphere. The objectives of the Russian NPOs are similar to those that operate abroad. NPOs worldwide are united by the endeavor for positive changes in society.

The number of NPOs in Russia exceeds 220 thousand. But they are still underdeveloped compared to the ones abroad for the following reasons. Firstly, the legislation on NPOs needs further development and keeps changing. This leads to uncertainty, transaction costs and the need for extra funding. Secondly, funding and state support for NPOs are insufficient and irregular in contrast to developed countries. The main problem is in the opacity of the funds' distributing mechanism. Thirdly, there is little public interest in the activities of NPOs. This is due to the lack of information about NPOs and their achievements in the media.

The non-profit sector is able to respond quickly to the new challenges and needs of various social groups (quicker than does the government) and to help easing social problems. The sector is exposed to lower administrative costs. Volunteers involved in NPOs' operation can also help a lot.

The activity of any NPO is for making the nation healthier and more educated. This leads to increased economic efficiency and accelerates economic growth. The non-profit sector also serves as a source of social innovations since many educational, managerial and information technologies, modern social work methods are initialized by NPOs and only then are adopted in governmental policies. The non-profit sector employs actively the socially vulnerable population thereby easing social tension. All the above are the arguments for supporting NPOs in Russia and helping them to become more sustainable and mature.

\section{References}

1. J. Boli, G.M. Thomas, World culture in the world polity: A century of international nongovernmental organization. American Sociological Review, 62(2), 171-190. DOI: 10.2307/2657298 (1997).

2. A.M. Eikenberry, J.D. Kluver, The marketization of the nonprofit sector: civil society at risk? Public Administration Review, 64(2), 132-140. DOI: 10.1111/j.1540-6210.2004.00355.x (2004).

3. M. Lyons, Third sector: The contribution of nonprofit and cooperative enterprise in Australia. Sydney: Allen \& Unwin (2001).

4. L.M. Salamon, The rise of the nonprofit sector. Foreign Affairs, 73(3), 111-124 (1994). 
5. B.A. Weisbrod, The nonprofit economy. Cambridge, Massachusetts: Harvard University Press (2009).

6. L.M. Salamon, The resilient sector revisited: The new challenge to nonprofit America. Washington, D.C.: Brookings Institution Press (2015).

7. L.M. Salamon, United Nations satellite account on non-profit and related institutions and volunteer work. New York, NY: United Nations (2018).

8. L.M. Salamon, W. Sokolowski, R. List, T. Stefan (Eds.), Global civil society: Dimensions of the nonprofit sector. Baltimore, Maryland: Institute for Policy Studies, Center for Civil Society Studies, Johns Hopkins University (2003).

9. B.S. McKeever, The nonprofit sector in brief 2015. Urban Institute. Center of Nonprofits and Philanthropy, October. URL: https://www.urban.org/sites/default/files/publication/72536/2000497-The-Nonprofit-Sector-in-Brief2015-Public-Charities-Giving-and-Volunteering.pdf (2015).

10. R.E. Anderson, Alleviating world suffering: The challenge of negative quality of life. Cham, Switzerland: Springer. DOI: 10.1007/978-3-319-51391-1 (2017).

11. G. Aldashev, T. Verdier, When NGOs go global: Competition on international markets for development donations. Journal of International Economics, 79(2), 198-210 (2009).

12. J. Huggett, Patterns of international non governmental organisation's growth. France, Paris: Open Editions (2012).

13. D. Lewis, The management of non-governmental development organizations. New York, NY: Routledge (2006).

14. J. Simeant, What is going global? The internationalization of French NGOs 'without borders'. Review of International Political Economy, 12(5), 851-883 (2005).

15. H. Teegen, J.P. Doh, S. Vachani, The importance of nongovernmental organizations (NGOs) in global governance and value creation: An international business research agenda. Journal of International Business Studies, 35(6), 463483 (2004).

16. N. Walliman, Research methods the basics. New York, NY: Routledge (2011).

17. Neil J. Salkind, Encyclopedia of research design. SAGE Publications. DOI: 10.4135/9781412961288 (2010).

18. L.M. Salamon, H. Anheier, (Eds.), Defining the nonprofit sector: A cross-national analysis. New York, NY: Manchester University Press (1997).

19. K.D. McCarty, V.A. Hodgkinson, R.D. Sumariwalla, \& Associates (Eds.), The nonprofit sector in the global community. San Francisco, California: Jossey-Bass Publishers (1992).

20. T. Lee, The rise of international nongovernmental organizations: A top-down or bottom-up explanation? Voluntas: International Journal of Voluntary and Nonprofit Organizations, 21(3), 393-416 (2010).

21.Federal'nyj zakon "O nekommercheskikh organizatsiyakh" ot 12.01 .1996 N 7-FZ. Retrieved from: http://www.consultant.ru/document/cons_doc_LAW_8824/ Accessed: 30.12 .2018 (1996).[in Rus.] 